\title{
BRAND IMAGE TERHADAP MINAT KONSUMEN MOBIL ISUZU PANTHER
}

\section{BRAND IMAG TOWARD AGAINTS CONSUMER INTEREST ISUZU PANTHER}

\author{
Dodi Agusra \\ Sekolah Tinggi Ilmu Ekonomi Persada Bunda Pekanbaru \\ dodi_agusra@yahoo.com
}

Submit, 20-04-2019 Accepted, 22-06-2019 Publish, 23-06-2019

\begin{abstract}
Business people in the automotive industry continue to strive for what they produce and offer, desired and received by consumers, which will then be purchased at the maximum purchase level with a high frequency of purchases. The research objective was to determine the effect of brand image on consumer interest in buying Isuzu Panther cars at PT. Astra International Tbk. Pekanbaru Branch. The research method used in this study is multiple linear regression analysis. The results of the study concluded that respondents agreed with the brand image of the Isuzu Panther car today as a fuelefficient car, a quality car, suitable for all terrain so that it adds to the rider's confidence and is an easy car to maintain and repair. Consumer interest in Isuzu Panther cars is considered good or interested consumers. The analysis using SPSS showed that the brand image has a very strong relationship with consumer interest in buying Isuzu Panther cars. Brand image has a positive effect on consumer interest, so if there is an increase in the brand image of the Isuzu Panther car, it will also lead to an increase in consumer interest in buying Isuzu Panther cars
\end{abstract}

Keywords : Brand Image, Consumer Interest, Isuzu Panther

\begin{abstract}
ABSTRAK
Para pelaku bisnis di industri otomotif terus berupaya agar apa yang mereka hasilkan dan mereka tawarkan, diinginkan dan di terima oleh konsumen, yang kemudian akan dibeli dalam tingkat pembelian yang maksimum dengan frekuensi pembelian yang tinggi. Tujuan penelitian adalah untuk mengetahui pengaruh brand image terhadap minat konsumen untuk membeli mobil Isuzu Panther pada PT. Astra International Tbk. Cabang Pekanbaru. Metode penelitian yang digunakan dalam penelitian ini adalah analisis regresi linear berganda. Hasil penelitian menyimpulkan bahwa responden setuju dengan brand image mobil Isuzu Panther saat sekarang ini sebagai mobil yang irit bahan bakar, mobil yang berkualitas, cocok untuk segala medan sehingga menambah kepercayaan diri pengendaranya dan merupakan mobil yang mudah dalam perawatan dan perbaikannya. Minat konsumen terhadap mobil Isuzu Panther dinilai baik atau konsumen berminat. Analisis dengan menggunakan SPSS didapatkan hasil bahwa brand image mempunyai hubungan yang sangat kuat terhadap minat konsumen untuk membeli mobil Isuzu Panther. Brand image berpengaruh positif terhadap minat konsumen, sehingga jika ada peningkatan terhadap brand image dari mobil Isuzu Panther, maka juga akan menimbulkan peningkatan terhadap minat konsumen untuk membeli mobil Isuzu Panther
\end{abstract}

Kata Kunci : Brand Image, Minat Konsumen, Isuzu Panther 


\section{PENDAHULUAN}

Pada saat ini, mobil bukan lagi sepenuhnya dianggap sebagai barang mewah akan tetapi sudah merupakan kebutuhan, dimana keberadaannya juga mencerminkan gaya hidup dan perilaku konsumen. Selain dilihat dari kacamata konsumen, perkembangan teknologi dunia otomotifpun sangat berpengaruh dalam pengembangan produk bidang usaha tersebut. Hal ini mendorong para produsen untuk menghasilkan produk berteknologi baru dalam jumlah besar dan jenis yang lebih bervariasi serta kualitas yang memadai. Berkembangnya industri otomotif dewasa inipun menyebabkan makin kompetitifnya persaingan, dimana produsen berlombalomba untuk menarik konsumen sebanyak mungkin.

Para pelaku bisnis di industri otomotif terus berupaya agar apa yang mereka hasilkan dan mereka tawarkan, diinginkan dan di terima oleh konsumen, yang kemudian akan dibeli dalam tingkat pembelian yang maksimum dengan frekuensi pembelian yang tinggi. Oleh karena itu produsen dituntut pula untuk mampu dan pintar dalam pemilihan strategi pemasaran produk yang akan digunakan dalam menjual produknya.

Jika dilihat secara umum, kecenderungan persaingan di dunia marketing saat ini tidak hanya disebabkan persaingan dalam hal harga tetapi sudah berkembang menjadi persaingan merek, dimana perusahaan berlomba untuk menancapkan citra merek mereka sedalam mungkin ke dalam benak konsumen. Sebaliknya di masyarakat terdapat bermacam-macam jenis orang dengan keinginan dan selera yang berbeda-beda pula.

Persaingan yang semakin kuat akan menciptakan customer sendirisendiri antar produk, karena persaingan ini akan membuat konsumen yakin dalam memilih dan membeli terhadap merk tertentu.

Keberadaan merek dianggap sebagai pilar bisnis sehingga dapat menarik minat konsumen untuk memakai produk tersebut. Setiap merek yang ditawarkan memiliki ciri khas sendiri yang membedakan dengan produk pesaing. Merek merupakan salah satu pertimbangan konsumen untuk menggunakan suatu produk. Merek merupakan suatu nama, simbol, tanda, atau desain atau kombinasi diantaranya, dan ditujukan untuk mengidentifikasi barang atau jasa dari seorang penjual atau kelompok penjual dan untuk membedakannya dari para pesaing. Untuk memahami sekaligus menarik minat konsumen, maka perusahaan harus memiliki citra merek yang kuat dibenak konsumen. Perusahaan yang berhasil membangun merek yang kuat akan memiliki nilai tambah dari perusahaan lain.

Isuzu adalah merupakan salah satu produsen kendaraan roda empat yang sudah lama ada dalam dunia otomotif di Indonesia. Khusus untuk Kota Pekanbaru, perusahaan yang menjual produk-produk mobil Isuzu salah satunya adalah PT. Astra International Tbk. Cabang Pekanbaru yang bertindak sebagai Sales Channel dari PT. Isuzu Astra Motor Indonesia sebagai Agen Tunggal Pemegang Merek Isuzu di Indonesia.

Dalam penelitian ini, penulis mengambil fokus penelitian adalah pada mobil Isuzu Phanter. Adapun alasan penulis memilih mobil Isuzu Phanter sebagai fokus penelitian adalah karena berdasarkan informasi yang penulis dapatkan dari pihak perusahaan, bahwa produk andalan mereka adalah mobil Isuzu Phanter. Selain itu saat sekarang ini, penjualan mobil Isuzu Panther secara nasional untuk kelas mobil MPV bermesin diesel diatas $1500 \mathrm{cc}$ masih 
kalah jika dibandingkan dengan produk Toyota yaitu pada Kijang Innova mesin diesel.

Isuzu Panther termasuk ke dalam kendaraan MPV untuk kelas menengah, jika dibandingkan dengan pesaingnya, Isuzu Panther merupakan kendaraan yang irit bahan bakar dengan rasio 1 Liter untuk $13 \mathrm{~km}$ dalam kota dan $16 \mathrm{~km}$ jika melakukan perjalanan keluar kota. Sedangkan pesaingnya untuk 1 liternya berkisar $9-12 \mathrm{~km}$.

Dalam penelitian ini diperoleh data yang menunjukan bahwa realisasi dari penjualan mobil Isuzu Phanter pada PT. Astra International Tbk. Cabang Pekanbaru periode 2013-2016 mengalami penurunan.

Terjadinya penurunan penjualan ini menunjukkan turunnya minat konsumen terhadap mobil Isuzu Panther dan juga disebabkan semakin ketatnya persaingan dalam penjualan mobil, karena pada saat sekarang semakin banyak bermunculan produk mobil dengan harga yang lebih murah dengan penawaran fasilitas dan fitur yang menarik. Maka dari itu, perusahaan otomotif harus dapat membangun citra merek yang bagus, agar konsumen tertarik untuk melakukan pembelian terhadap produk mereka. Isuzu Phanter sendiri, brand image yang telah tertanam dibenak konsumen dari dulu adalah mobil yang hemat atau irit bahan bakar. Selain itu juga merupakan kendaraan yang memiliki daya jelajah tinggi, baik untuk medan-medan yang berat ataupun untuk perjalanan yang panjang.

Berdasarkan hal tersebut di atas, maka penulis tertarik untuk melakukan penelitian dengan judul : Pengaruh Brand Image Terhadap Minat Konsumen Mobil Isuzu Panther pada PT. Astra International Tbk. Cabang Pekanbaru

Pemasaran merupakan kegiatan bisnis yang berbeda dengan kegiatan bisnis lainnya. Pada kegiatan pemasaran para manajer berurusan dengan konsumen, baik konsumen intern perusahaan maupun konsumen ekstern perusahaan.

Menurut Rangkuti (2004) mendefinisikan citra merek sebagai sekumpulan asosiasi merek yang terbentuk di benak konsumen. Dimana asosiasi merek merupakan segala hal yang berkaitan dengan ingatan mengenai sebuah merek.

Sedangkan menurut Rangkuti (2004) citra merek adalah bagaimana merek itu terlihat.

Dari pengertian di atas dapat disimpulkan bahwa citra merek merupakan hasil persepsi dan pemahaman konsumen mengenai merek suatu produk yang dilihat, dipikirkan atau dibayangkan. Dengan menciptakan citra merek dari suatu produk tentu akan sangat berguna bagi para konsumen, karena pada nantinya citra merek akan sangat memengaruhi persepsi konsumen dan penilaian konsumen terhadap alternatif merek yang dihadapinya (Oktiani \& Khadafi, 2018).

Menurut Rangkuti pengukuran terhadap merek mempunyai enam tingkat pengertian sebagai berikut:

1. Atribut : atribut perlu dikelola agar pelanggan mengerti dan mengetahui dengan pasti atribut-atribut apa yang terdapat dalam merek.

2. Manfaat : merek juga mempunyai manfaat karena pada dasarnya konsumen tidak membeli atribut tetapi membeli manfaat. Produsen harus dapat menerjemahkan atribut menjadi manfaat fungsional maupun manfaat emosional.

3. Nilai : merek juga menyatakan sesuatu tentang nilai bagi produsen, merek juga mempunyai nilai tinggi akan dihargai oleh konsumen sebagai merek yang berkelas, sehingga dapat mencerminkan siapa pengguna merek tersebut. 
4. Budaya : merek juga mencerminkan budaya tertentu apakah itu budaya produsennya maupun budaya penggunanya.

5. Kepribadian : merek mempunyai kepribadian yaitu kepribadian bagi penggunanya. Dan diharapkan dengan memakai tercermin bersamaan dengan merek yang ia akan gunakan.

6. Pemakai : merek juga menunjukkan jenis konsumen pemakai merek tersebut negatif dan melemahkan kemampuan perusahaan dalam persaingan.

Perilaku konsumen adalah tindakan yang langsung terlibat dalam mendapatkan, mengkonsumsi, dan menghabiskan produk atau jasa, termasuk proses keputusan yang mendahului dan menyusuli tindakan ini (Setiadi, 2003)

Menurut Schiffman dan Kanuk dalam Klimchuk (2007), perilaku konsumen adalah perilaku yang diperlihatkan konsumen dalam mencari, membeli, menggunakan, mengevaluasi dan menghabiskan produk dan jasa yang mereka harapkan akan memuaskan kebutuhan mereka.

Secara teoritis, setiap kali seseorang membeli suatu barang atau jasa, ia berharap bahwa barang atau jasa tersebut akan mampu memberikan kegunaan maksimum (Syaleh, 2017). Dengan kata lain, setiap konsumen adalah rational economic man yang memiliki alasan rasional dan membuat pilihan rasional dalam setiap pembelian produk dan jasa (Tjiptono, 2005).

Menurut Kotler (2009) ada lima proses tahap keputusan pembelian oleh konsumen sebagai berikut :

1. Pengenalan Masalah, proses membeli diawali saat pembeli menyadari adanya masalah kebutuhan. Pembeli menyadari terdapat perbedaan antara kondisi yang sesuangguhnya dengan kondisi yang diinginkan. Kebutuhan ini dapat disebabkan oleh rangsangan internal dalam kasus pertama dan kebutuhan normal seseorang, yaitu rasa lapar, dahaga atau seks meningkat hingga tingkat tertentu dan berubah menjadi dorongan, suatu kebutuhan dapat juga timbul karena disebabkan rangsangan eksternal seseorang yang melewati sebuah toko roti dan melihat roti yang baru selesai dibakar dapat merangsang rasa laparnya.

2. Pencarian Informasi, konsumen yang mulai timbul minatnya akan terdorong untuk mencari informasi lebih banyak. Dapat dibedakan dua tingkat yaitu keadaan tingkat pencarian informasi yang sedangsedang saja yang disebut perhatian yang meningkat. Pencarian informasi secara aktif dimana ia mencari bahan-bahan bacaan, menelepon teman-temannya, dan melakukan kegiatan-kegiatan mencari untuk mempelajari yang lain. Umumnya jumlah aktivitas pencarian konsumen akan meningkat bersamaan dengan konsumen berpindah dari situasi pemecahan masalah yang terbatas ke pemecahan masalah yang ekstensif.

3. Evaluasi Alternatif, setelah memiliki informasi yang cukup lengkap, biasanya konsumen mengevaluasi alternatif yang ada. Dalam mengevaluasi konsumen dapat menggunakan kalkulasi yang ketat dan berfikir tentang barang yang akan dibeli, namun adakalanya konsumen hanya mengandalkan intuisi saja dan bersikap impulsif.

4. Keputusan Membeli, konsumen pada tahap evaluasi membentuk preferensi terhadap merek-merek yang terdapat pada perangkat 
pilihan. Konsumen mungkin juga membentuk tujuan membeli untuk merek paling disukai. Walaupun demikian, dua faktor dapat mempengaruhi tujuan membeli dan keputusan membeli. Faktor yang utama ialah sikap orang lain. Sikap orang lain akan mengurangi alternatif pilihan seseorang akan tergantung pada dua hal : (1) Intensitas sikap negatif orang lain tersebut terhadap alternatif pilihan konsumen. (2) Motivasi konsumen untuk menuruti keinginan orang lain tersebut. Semakin tinggi intensitas sikap negatif orang lain semakin besar kemungkinan konsumen akan menyesuaikan tujuan pembeliannya.

Menurut Kotler dan Keller (2007), minat beli konsumen adalah sebuah perilaku konsumen dimana konsumen mempunyai keinginan dalam membeli atau memilih produk, berdasarkan pengalaman dalam memilih, menggunakan dan mengkonsumsi atau bahkan menginginkan suatu produk

Berdasarkan penjelasan di atas, maka dapat disimpulkan bahwa minat konsumen adalah keinginan dari konsumen untuk melakukan pembelian terhadap suatu barang.

Menurut Simamora (2003), sebelum membeli produk, pasar sasaran harus kenal dulu produknya. Kemudian, kalau ada minat, baru beli. Jadi, prosesnya terdiri dari kenal, minat, beli. Berdasarkan hal ini, maka minat konsumen berada pada area afektif dimana konsumen mulai timbul perasaan suka dan yakin akan produk yang disukainya, setelah itu produk tersebut akan dikonsumsi. Area afektif ini, meliputi kesukaan (liking), pilihan (Preference), keyakinan (Conviction)

Berdasarkan uraian yang telah dikemukakan sebelumnya, maka hipotesis dalam penelitian ini adalah: "brand image berpengaruh positif dan

signifikan terhadap minat konsumen membeli mobil Isuzu Phanter pada PT. Astra International Tbk. Pekanbaru"

\section{METODE PENELITIAN \\ Tempat Penelitian}

Penelitian ini dilakukan di PT. Astra International Tbk. Cabang Pekanbaru yang beralamatkan di Jalan Soekarno Hatta Pekanbaru.

\section{Populasi dan Sampel}

Populasi dalam penelitian ini adalah konsumen yang telah melakukan pembelian mobil merek Isuzu Phanter pada PT. Astra International Tbk. Cabang Pekanbaru, yang mana jumlah populasinya adalah sebanyak 80 responden yang merupakan konsumen yang telah melakukan pembelian mobil merek Isuzu Phanter pada tahun 20152016.

Dalam menentukan jumlah sampel menggunakan metode sensus, dimana seluruh populasi yang berjumlah 88 unit terjual yang digunakan oleh 88 orang pembeli atau pengguna mobil merek Isuzu Panther dijadikan sebagai sampel.

\section{Jenis dan Sumber Data}

Data primer Yaitu data yang
diperoleh secara langsung $\begin{array}{r}\text { dari } \\ \text { responden yang terpilih pada lokasi }\end{array}$
penelitian. Data primer diperoleh dengan
memberikan daftar pertanyaan /
kuisioner yang berisi tentang variabel
yang diteliti. Data sekunder yaitu data
yang diperoleh melalui studi dokumen
dengan mempelajari berbagai tulisan
melalui buku, jurnal, majalah, informasi
dari perusahaan ataupun penelitian
lainnya sebagai referensi. Adapun data
sekunder dalam penelitian ini adalah
data penjualan mobil Isuzu Phanter,
gambaran umum PT. Astra International
Tbk. Cabang Pekanbaru, struktur
organisasi dan teori-teori yang
berhubungan dengan variabel yang
diteliti yang diperoleh dari buku-buku
dan penelitian terdahulu.




\section{Teknik Pengumpulan Data}

Untuk pengumpulan data pada penelitian ini dilakukan dengan cara menggunakan kuiseoner dan wawancara.

\section{Motode Analisis Data}

Metode analisis data yang digunakan dalam penelitian ini adalah dengan metode deskriptif yaitu membahas permasalahan penelitian dengan menguraikan dan menjelaskan berdasarkan data yang diperoleh serta interpetasikan sesuai dengan teori-teori yang relevan sehingga dapat menggambarkan keadaan yang terjadi (Umar, 2007).

Untuk menganalisis data digunakan metode analisis statistik, yaitu dengan menggunakan program komputer Statistical Package for Social Science (SPSS) 17.0. Dalam melakukan pengolahan dan analisis data maka digunakan analisis kuantitatif dengan menggunakan regresi linear sederhana.

Regresi linear sederhana adalah untuk menganalisis hubungan dan pengaruh secara linier antara variabel dependen dengan variabel independen (Sunyoto, 2009). Untuk mengetahui pengaruh brand image terhadap perilaku konsumen, maka dilakukan dengan analisis regresi linier dengan model sebagai berikut (Sunyoto, 2009) :

$$
\mathbf{Y}=\mathbf{a}+\mathbf{b X}
$$

Dimana : $\quad \mathrm{Y}=$ Minat Konsumen

$$
\begin{aligned}
& \mathrm{a}=\text { Konstanta } \\
& \mathrm{b}=\text { Koefisien } \\
& \mathrm{X}=\text { Brand Image }
\end{aligned}
$$

\section{Definisi Operasional Variabel Penelitian}

Adapun definisi operasional dalam penelitian ini yaitu :

1. Brand image adalah hasil persepsi dan pemahaman konsumen mengenai mobil merek Isuzu
Phanter yang dilihat, dipikirkan atau dibayangkan.

2. Indikator dari brand image adalah atribut, manfaat, nilai, budaya, kepribadian dan pemakai.

3. Minat konsumen adalah keinginan dari konsumen untuk melakukan pembelian mobil merek Isuzu Phanter pada PT. Astra International Tbk. Cabang Pekanbaru.

4. Indikator dari minat konsumen adalah kesukaan (liking), pilihan (preference), keyakinan (conviction).

5. Variabel dalam penelitian ini terdiri dari variabel independen yaitu brand image (X) serta variabel dependen yaitu minat konsumen (Y).

Untuk memudahkan arah penelitian ini, maka dilakukan operasional variabel yang tertuang pada tabel 1 :

\section{Tabel 1}

\section{Definisi Operasional Variabel}

\begin{tabular}{lll}
\hline Variabel & \multicolumn{1}{c}{ Definisi } & \multicolumn{1}{c}{ Indikator } \\
\hline Brand & Sekumpulan & 1. Atribut \\
Image & asosiasi merek & 2. Manfaat \\
$(\mathrm{X})$ & yang terbentuk di & 3. Nilai \\
& benak konsumen. & 4. Budaya \\
& (Rangkuti, 2004) & 5. Kepribadian \\
& & 6. Pemakai
\end{tabular}

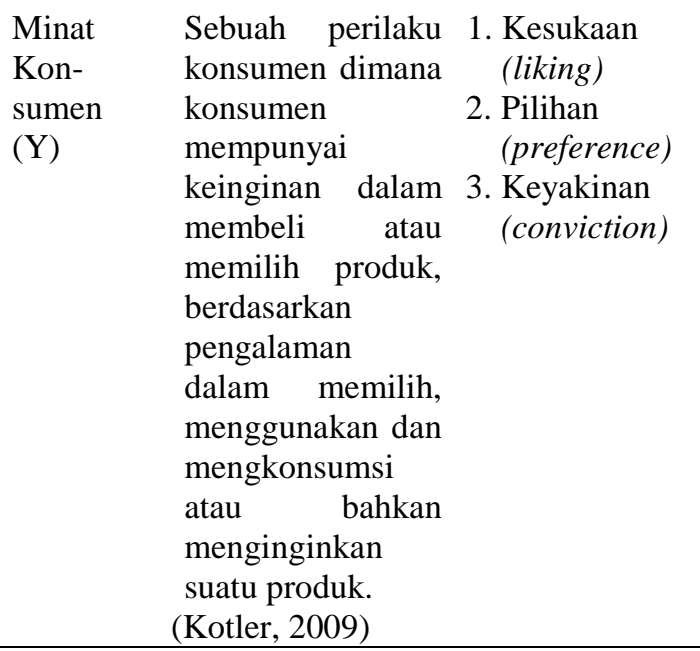

Sumber: Data olahan 
HASIL DAN PEMBAHASAN

Brand Image Mobil Isuzu Phanter

Brand image adalah hasil persepsi

dan pemahaman konsumen mengenai mobil merek Isuzu Phanter yang dilihat, dipikirkan atau dibayangkan. Brand image mobil Isuzu Panther pada PT. Astra International, Tbk Cabang Pekanbaru yang dapat dilihat dari enam indikator yaitu atribut, manfaat, nilai, budaya, kepribadian dan pemakai.

Rekapitulasi tanggapan responden terhadap brand image mobil Isuzu Panther pada PT. Astra International, Tbk Cabang Pekanbaru dapat dilihat pada tabel 2 berikut:

Tabel 2

Rekapitulasi Tanggapan terhadap Brand Image

\begin{tabular}{clcc}
\hline No. & Indikator & Skor & Kategori \\
\hline & & & \\
2 & Manfaat & 620 & Setuju \\
3 & Nilai & 625 & Setuju \\
4 & Budaya & 495 & Kurang Setuju \\
5 & Kepribadian & 616 & Setuju \\
6 & Pemakai & 492 & Kurang Setuju \\
& & & \\
& Jumlah & $\mathbf{3 . 4 5 3}$ & Setuju \\
\hline
\end{tabular}

Sumber : Data Olahan, 2017

Dari tabel 2 dapat dilihat bahwa secara keseluruhan, tanggapan responden terhadap brand image mobil Isuzu Panther dinilai setuju, yang artinya responden setuju dengan brand image mobil Isuzu Panther saat sekarang ini sebagai mobil yang irit bahan bakar, mobil yang berkualitas, cocok untuk segala medan sehingga menambah kepercayaan diri pengendaranya dan merupakan mobil yang mudah dalam perawatan dan perbaikannya. Namun demikian, dari hasil ini masih terdapat kekurangan dalam hal model dari mobil Isuzu Panther yang masih sama dari dulu sampai dengan sekarang. Selain itu adanya kesan yang timbul bahwa Isuzu Panther adalah mobil untuk orang yang sudah berumur, bukan bagi remaja, karena sebagian besar penggunanya memang bukan remaja.

Minat Konsumen Terhadap Mobil Isuzu Phanter

Minat konsumen adalah keinginan dari konsumen untuk melakukan pembelian mobil Isuzu Panther pada PT. Astra International, Tbk Cabang Pekanbaru. Minat beli konsumen dapat dilihat dengan indikator kesukaan (liking), pilihan (Preference) dan keyakinan (Conviction).

Rekapitulasi tanggapan responden atas minat konsumen terhadap mobil Isuzu Panther pada PT. Astra International, Tbk Cabang Pekanbaru dapat dilihat pada tabel 3 .

Tabel 3

Rekapitulasi Tanggapan tehadap Minat Konsumen

\begin{tabular}{clcl}
\hline No & Indikator & Skor & Ktiteria \\
\hline 1 & Kesukaan & 545 & Berminat \\
2 & Pilihan & 565 & Berminat \\
3 & Keyakinan & 560 & Berminat \\
& & & \\
& Jumlah & $\mathbf{1 . 6 7 0}$ & Berminat \\
\hline
\end{tabular}

Sumber : Data Olahan, 2017

Dari tabel 3, dapat dilihat bahwa rekapitulasi tanggapan responden terhadap minat konsumen pada mobil Isuzu Panther pada PT. Astra International, Tbk Cabang Pekanbaru dinilai berminat. Seperti yang telah dijelaskan pada variabel brand image, pada variabel minat konsumen ini, konsumen juga berminat terhadap mobil Isuzu Panther dikarenakan Isuzu Panther merupakan mobil yang sudah lama hadir di Indonesia sebagai mobil dengan mesin diesel dan sampai sekarang tetap fokus pada mobil dengan mesin diesel. Selain itu, minat konsumen akan mobil Isuzu Panther adal dikarenakan mobil Isuzu Panther yang irit bahan bakar dan mudah dalam melakukan perawatan dan perbaikannya.

Hal ini jugalah yang menimbulkan minat konsumen untuk 
merekomendasikannya kepada orang lain jika ingin membeli mobil dengan mempertimbangkan untuk mencari mobil yang berkualitas, nyaman dan ekonomis.

\section{Pngaruh Brand Image terhadap Perilaku Konsumen Mobil Isuzu Phanter}

\section{Analisis Regresi Linier Sederhana}

Analisis regresi linear sederhana digunakan untuk menganalisis hubungan linear antara satu variabel independen dengan satu variabel dependen. Variabel Independen dalam penelitian ini adalah brand image (X) dan variabel dependennya adalah minat konsumen (Y) terhadap mobil merek Isuzu Panther pada PT. Astra International, Tbk Cabang Pekanbaru. Berikut dapat dilihat korelasi atau hubungan dan besarnya sumbangan yang diberikan variabel brand image terhadap minat konsumen akan mobil Isuzu Panther.

\section{Tabel 4}

\section{Model Summary}

\begin{tabular}{l|c|r|r|r}
\hline Model & $\mathrm{R}$ & $\begin{array}{c}\mathrm{R} \\
\text { Square }\end{array}$ & $\begin{array}{c}\text { Adjusted R } \mathrm{R} \\
\text { Square }\end{array}$ & $\begin{array}{l}\text { Std. Error } \\
\text { of the } \\
\text { Estimate }\end{array}$ \\
\hline 1 & $.877^{\mathrm{a}}$ & .770 & .767 & 1.360 \\
\hline
\end{tabular}

a. Predictors: (Constant), Brand Image

b. Dependent Variable: Minat Konsumen

Sumber : Olahan SPSS, 2017

Berdasarkan tabel 4 diketahui nilai $\mathrm{R}$ yang berarti korelasi atau hubungan antara variabel brand image dengan variabel minat konsumen sebesar 0,877, yang berarti variabel brand image (X) mempunyai hubungan yang sangat kuat terhadap variabel minat konsumen (Y). Kemudian nilai koefisien determinasi $\left(\mathrm{R}^{2}\right) \quad$ untuk menunjukkan besarnya sumbangan yang diberikan didapatkan sebesar 0,770 , yang artinya variabel brand image (X) memberikan sumbangan sebesar $77 \%$ terhadap variabel minat konsumen (Y) dan sisanya sebesar $23 \%$ dipengaruhi oleh variabel lainnya yang tidak diteliti dalam penelitian ini. Hal ini menunjukkan bahwa minat konsumen akan mobil Isuzu Panther lebih dominan dipengaruhi oleh brand image dibandingkan oleh variabel lainnya.

Uji t

Untuk mengetahui kebenaran hipotesis yang telah diajukan oleh penulis sebelumnya maka dilakukan uji-t dengan cara membandingkan nilai $t$ table dengan $\mathrm{t}$ hitung. Dimana $\mathrm{t}$ hitung diperoleh dari hasil keluaran program SPSS. Sementara t tabel dilihat dengan derajat bebas $\mathrm{n}-\mathrm{k}$, dimana $\mathrm{n}$ adalah jumlah sampel dan $\mathrm{k}$ adalah jumlah variabel yang digunakan.Rumus hipotesisnya adalah :

Ho Brand image tidak berpengaruh terhadap minat konsumen

Ha Brand image berpengaruh terhadap minat konsumen

Dengan kriteria pengujian :

Jika $t$ hitung $<\mathrm{t}$ tabel maka Ho diterima dan Ha ditolak

Jika $t$ hitung $>t$ tabel maka Ho ditolak dan Ha diterima

Pada tabel Coefficients berikut yang merupakan hasil keluaran dari SPSS didapatkan hasil dari thitung.

\section{Coefficients $^{\mathrm{a}}$}

\begin{tabular}{|c|c|c|c|c|c|c|}
\hline \multirow{2}{*}{\multicolumn{2}{|c|}{ Model }} & \multicolumn{2}{|c|}{$\begin{array}{l}\text { Unstandardized } \\
\text { oefficients }\end{array}$} & \multirow{2}{*}{$\begin{array}{c}\begin{array}{c}\text { Standardized } \\
\text { Coefficients }\end{array} \\
\text { Beta } \\
\end{array}$} & \multirow[b]{2}{*}{$\mathrm{T}$} & \multirow[b]{2}{*}{ Sig. } \\
\hline & & B & $\begin{array}{l}\text { Std. } \\
\text { Error }\end{array}$ & & & \\
\hline \multirow[t]{2}{*}{1} & Constant) & 2.736 & 1.386 & & 1.974 & .052 \\
\hline & $\begin{array}{l}\text { Brand } \\
\text { Image }\end{array}$ & .445 & .028 & .877 & 15.624 & .000 \\
\hline
\end{tabular}

a. Dependent Variable: Minat Konsumen Sumber : Olahan SPSS, 2017

Berdasarkan tabel 4, diketahui nilai $\mathrm{t}$ hitung sebesar 15,624 dengan signifikansi 0,000 . Jika dibandingkan dengan nilai $t$ tabel yang dapat dilihat pada tabel statistik pada signifikansi 0,05 dengan derajat kebebasan df $=\mathrm{n}-2=$ $72-2=73$. Hasil yang diperoleh untuk 
t tabel adalah sebesar 1,669. Jadi t hitung yang diperoleh lebih besar dari t tabel, yaitu : $15,624>1,669$. Selanjutnya, berdasarkan table 4, juga didapatkan persamaan regresi linear sebagai berikut $\mathbf{Y}=\mathbf{a}+\mathbf{b X}$ $Y=2,736+0,445 X$

Dari persamaan regresi di atas menunjukkan koefisien regresi yang diperoleh dari hasil program SPSS hasilnya adalah positif. Hal ini berarti bahwa jika ada peningkatan atas brand image mobil Isuzu Panther, maka akan menimbulkan peningkatan terhadap minat konsumen untuk membeli mobil Isuzu Panther.

Dari penjealsan di atas, dimana didapatkan nilai t hitung lebih besar dari t tabel serta bernilai positif, ini berarti bahwa brand image berpengaruh terhadap minat konsumen dan berarti juga bahwa Ho ditolak dan Ha diterima sehingga hipotesis "Diduga brand image berpengaruh positif dan signifikan terhadap minat konsumen membeli mobil Isuzu Phanter pada PT. Astra International Tbk. Pekanbaru”, dapat diterima.

Berdasarkan hal ini, maka dapat disimpulkan bahwa brand image sebuah produk merupakan faktor yang sangat mempengaruhi seorang konsumen untuk melakukan pembelian terhadap produk tersebut. Dengan adanya pengaruh ini diharapakan adanya peningkatan penjualan terhadap mobil Isuzu Panther, hasil penelitian ini sejalan dengan penelitian Santoso (2018) dimana citra merek berpengaruh terhadap keputusan pembelian.

\section{PENUTUP}

\section{Kesimpulan}

1. Brand image mobil Isuzu Panther saat sekarang ini dinilai sebagai mobil yang irit bahan bakar, mobil yang berkualitas, cocok untuk segala medan sehingga menambah kepercayaan diri pengendaranya dan merupakan mobil yang mudah dalam perawatan dan perbaikannya. Namun masih terdapat kekurangan dalam hal model dari mobil Isuzu Panther yang masih sama dari dulu sampai dengan sekarang. Selain itu adanya kesan yang timbul bahwa Isuzu Panther adalah mobil untuk orang yang sudah berumur.

2. Minat konsumen pada mobil Isuzu Panther dinilai berminat dikarenakan Isuzu Panther merupakan mobil yang sudah lama hadir di Indonesia sebagai mobil dengan mesin diesel dan sampai sekarang tetap fokus pada mobil dengan mesin diesel. Sehingga hal ini menimbulkan minat konsumen untuk merekomendasikannya kepada orang lain dengan pertimbangan mobil yang berkualitas, nayaman dan ekonomis.

3. Brand image mempunyai hubungan yang sangat kuat dan berpengaruh positif terhadap minat konsumen untuk membeli mobil Isuzu Panther pada PT. Astra International, Tbk Cabang Pekanbaru. jika terdapat peningkatan terhadap brand image dari mobil Isuzu Panther, maka juga akan menimbulkan peningkatan terhadap minat konsumen untuk membeli mobil Isuzu Panther pada PT. Astra International, Tbk Cabang Pekanbaru.

\section{Saran}

Berdasarkan kesimpulan yang telah diambil, maka saran yang dapat penulis sampaikan adalah sebagai berikut:

1. Perusahaan harus mampu mempertahankan dan meningkatkan brand image dari mobil Isuzu Panther yang bisa dilakukan dengan memberikan pelayanan pasca penjualan yang baik kepada konsumen. 
2. Perusahaan harus mampu mempertahankan dan meningkatkan minat konsumen terhadap mobil Isuzu Panther dengan melakukan perubahan yang signifikan pada model Isuzu Panther, seperti yang dilakukan oleh Toyota Kijang. PT. Astra International, Tbk Cabang Pekanbaru harus dapat memberikan masukan tentang hal ini kepada PT. Isuzu Astra Motor Indonesia.

\section{DAFTAR PUSTAKA}

Klimchuk, Marianne R. dan Krasocev Sandra A, (2007). Desain Kemasan : Perencanaan Merek Produk yang Berhasil Mulai dari Konsep Sampai Penjualan. Jakarta: Erlangga

Kotler, Philip, (2009).Manajemen ."Manajemen Pemasaran.(edisi millennium). Jilid I. Jakarta: PT. Indeks kelompok Gramedia.

Kotler, dan Keller, (2007). Manajemen Pemasaran. (Benyamin Molan: Terjemahan). Edisi 12. Jakarta : PT. Perca.

Oktiani, A., \& Khadafi, R. (2018). Pengaruh Brand Awareness dan Brand Image serta Word Of Mouth terhadap Brand Trust dan Pembentukan Brand Loyalty pada Pelanggan Cbezt Friedchiken Kecamatan Genteng Banyuwangi. Journal of Economic, Bussines and Accounting (COSTING), 1(2), 269-282. doi:10.31539/costing.v1i2.259

Rangkuti. (2004). The Power of Brand : Resep Jitu Meraih Personal Brand yang Unggul. Jakarta: Gramedia Pustaka Utama.
Santoso, P. H. (2018). Analisis Pengaruh

Harga, Citra Merek, dan Kredibilitas Perusahaan terhadap Niat Membeli Konsumen pada Produk Kawasaki di Kota Yogyakarta. Journal of Economic, Bussines and Accounting (COSTING), 1(2), 209-220. doi:10.31539/costing.v1i2.208

Setiadi, Nugroho J, (2003). Perilaku Konsumen: Konsep dan Implikasi untuk Strategi dan Penelitian Pemasaran. Cetakan Kedua. Jakarta: Prenata Media.

Simamora, Bilson, (2003). Membongkar Kotak Hitam Konsumen. Jakarta: Gramedia Pustaka Utama.

Sunyoto, Danang, (2009). Analisis Regresi dan Uji Hipotesis. Yogyakarta: Medpress.

Syaleh, H. (2017). Pengaruh Kualitas Produk, Harga, Promosi dan Tempat Pendistibusian Terhadap Keputusan Pembelian Sepeda Motor Yamaha Pada Perusahaan Tjahaja Baru Bukittinggi. Journal of Economic, Bussines and Accounting (COSTING), 1(1), 6882. doi:10.31539/costing.v1i1.16

Tjiptono, F. (2005). Brand Management and Strategy. Yogyakarta: ANDI.

Umar, Husein, (2007). Metode Penelitian Untuk Skripsi dan Tesis Bisnis. Raja Grafindo Persada. Jakarta 